\title{
HUMAN RightS OF PRISONERS IN JAPAN
}

\author{
Kiyoshi Yamashita*
}

In this paper the author provides a practitioner perspective on the human rights of prisoners in Japan, with particular reference to the treatment of persons detained pending trial, and to seminal decisions of the Japanese courts in a civil claim against the State for violating the rights of a prisoner to the protection of their human dignity.

\section{INTRODUCTION}

The human rights of prisoners are said to be the "weak" human rights. The weakness derives partly from the nature of the rights themselves where a suspect or convict has to claim their rights while at the same time they are subject to legal sanction for violating others' human rights. The weakness also derives from the fact that the life, including the claims for rights, of suspects or convicts is under strict supervision and regulation by police and prison authorities. Prisoners are excluded and isolated from the outside community, which makes their lives very different and passive in many aspects.

As is common in other jurisdictions in the world, there are two kinds of detainees in Japan: prisoners who have already been found guilty and are detained as a result of judicial decision, and suspects who have been arrested and are waiting for trial. Under the Prison Act of 1908, prisoners are detained in one of the four kinds of cells in a prison according to their conviction and sentence. ${ }^{1}$ Suspects should be detained in a prison, but they are usually detained in a substitute prison which is attached to a local police station. $^{2}$ In Part II of this article, the two types of detainees are discussed.

* Attorney at Law, Osaka; Chairperson, Committee for the Ratification of the Optional Protocol of the ICCPR, of the Osaka Bar Association.

1 Prison Act of 1908, c 28, art 1 as amended. The four cells are those for (1) prisoners imprisonment with labour, (2) imprisonment without labour, (3) imprisonment for less than 30 days, and (4) for criminal defendants. Prisoners sentenced to the death penalty are detained in the fourth category of prison.

2 Article 1(3) of the Prison Act. It is provided that "a place of detention attached to police stations can be used as a substitute prison". 


\section{CONDITION AND STATUS OF PRISONERS}

\section{A Conditions of Prisoners in Japanese Prisons}

Prisoners who are serving their sentence must follow the rules and regulations of the prison and must not be guilty of "shameful" behaviour. These rules are precisely determined in relation to their work, time to go to bed, dining, exercise and walking, etc the list includes nearly 120 subjects. $^{3}$ Prisoners are punished or disciplined if they act contrary to these rules.

There are prisoners who have complained as follows:

"I wish the authority would lengthen the time of meeting and interview with my relatives and friends, because we are not allowed to see visitors longer than 10 minutes once a month, currently."

"I would like to rest on soft "tatami" mats instead of thin "goza" sheet because it is very uncomfortable to rest on goza, and I think I am getting weaker and my skin is getting thinner."

"I would like to live in a much better condition in prison so that I can control my own health and can be rehabilitated for a comeback to society."

I believe that the above claims are modest and reasonable.

Many of these rules are "enforced for the benefit of prisoners" as are other regulations based on the current laws and statutes. However, they do not have any sense of protecting the human rights of the imprisoned. They also lack a philosophy of promoting rehabilitation for the detained to return to the outside society. It is necessary to stress that most of the rules are not of humanistic nature at all, having detainees obey the rules and not being able to express an emotional feeling as a human being. These rules treat the imprisoned only as an object who needs to be controlled. It is obvious that these rules are against the global standards of criminal punishment. ${ }^{4}$

3 Prison Inmates Guidelines of the Osaka Prison. Each prison has its own prison rules according to the national Prison Act Regulations of 1908, Ministry of Justice Order No 18. See also, Subcommittee for the Study of Prison Act, Committee for the Promotion of Human Rights, of the Osaka Bar Association, Interim Report on Actual Treatment of Offenders at Osaka Prison, March, 1986.

4 For a detailed description of the treatment of the detainees, see Japan Federation of Bar Associations (JFBA), A Report on the Application and Practice in Japan of the International Covenant on Civil and Political Rights, at paras 313-87, (Tokyo, JFBA, 1993). This report was submitted to the Human Rights Committee in 1993 as a counter report to the Third Periodic Report of Japan. 


\section{B Violation of International Human Rights}

In 1977, Japan ratified two of the most important human rights treaties: the International Covenant on Civil and Political Rights (ICCPR), and the International Covenant on Economic, Social and Cultural Rights (ICESCR). Unlike New Zealand and Australia, Japan adopts a system of law where treaties, when ratified by the Diet, have direct force as domestic law. Thus, treaties such as the above have direct applicability in domestic courts without any implementing act of the Diet. Also, in Japan as in foreign countries, it is accepted that the Universal Declaration of Human Rights of 1948 is international customary law. The international human rights law applicable in Japanese courts of law, is basically both of the treaties as international agreements and the declaration as international customary law.

The Japanese Constitution of $1946^{5}$ provides in article 98 (2) that Japan has to enforce international treaties which it has ratified and to honour international customary law. ${ }^{6}$ Therefore, these treaties and customary law have legal effect and validity as domestic law. At the same time, it is an established rule of legal interpretation that national laws in violation of these treaties and customary law do not have any effect as law of the country.

For example, article 10 (1) of ICCPR provides that "All persons deprived of their liberty shall be treated with humanity and with respect for the inherent dignity of the human person." However, the article does not give in detail any specific and actual context of treating people in humanistic way for the inherent dignity of the human person. In order to fill the gap, other legal standards should be consulted. And, here, as was discussed in the First UN Congress on the Prevention of Crime and the Treatment of Offenders held in Geneva in 1955, and followed by the approval of the UN Economic and Social Council in 1957, the "Standard Minimum Rules for the Treatment of Prisoners" have been established as the guideline for the treatment of offenders for more than 40 years. ${ }^{7}$ The guidelines should serve not only as a guideline for legal interpretations in Japan but also as an international standard.

The Standard Minimum Rules, for instance, provide that "Imprisonment and other measures which result in cutting an offender off from the outside world are afflictive by the very fact of taking from the person the right of self-determination by depriving him

5 Promulgated on 3 November 1946 and put into force on 3 May 1947.

6 Section 2 of art 98 provides that "Treaties concluded by Japan and the established law of nations shall be faithfully observed".

7 Standard Minimum Rules for the Treatment of Prisoners, Resolution 663 C (XXIV) of 31 July 1957 and 2076 (LXII) of 13 May 1977, UN Economic and Social Council, reprinted in A Compilation of International Instruments, Vol 1 (First Part), at 243 et seq, UN, ST/HR/1/Rev 4, 1993. 
of his liberty." "Therefore the prison system shall not, except as incidental to justifiable segregation or the maintenance of discipline, aggravate the suffering inherent in such a situation" (57th Rule). It also provides that "Discipline and order shall be maintained with firmness, but with no more restriction than is necessary for safe custody and a wellordered community life" (27th Rule). Further, "The regime of the institution should seek to minimize any differences between prison life and life at liberty which tend to lessen the responsibility of the prisoners or the respect due to their dignity as human beings" (60th Rule). The practices under Japanese Prison Act relating to exercise, medication, transportation, newspapers, use of the library and so on, are obviously against these rules.

Moreover, the Standard Minimum Rules state that "Corporal punishment, punishment by placing in a dark cell, and all cruel, inhuman or degrading punishments shall be completely prohibited as punishments for disciplinary offences" (31st Rule). However, the Prison Act in Japan contains sanctions, such as temporary suspension of exercise (which cannot exceed 5 days), decreasing payment for work inside the prison, decreasing the amount of food (no longer than 10 days), being ordered to sit on heels all day long without walking around (no longer than 2 months, with surveillance while bathing), and prohibiting the prisoner from leaving the cell all day long with the light off (no longer than 7 days). These sanctions can be the exact kind of punishments which the Minimum Standards prohibit. With these rules and practices, the Prison Act of 1908 is clearly in contravention of the Standard Minimum Rules and ICCPR. Therefore, it should be null and void.

\section{Human Rights of Detainees in Substitute Prisons}

Japan has a different legal system from the Western world in relation to the treatment of suspects who are forced to stay in substitute prisons in police stations. Detention in a substitute prison is unique in Japanese criminal justice system. The following is an example of a murder suspect who was detained in a substitute prison. The case was pending trial at the Osaka District Court when first reported in October 1988. ${ }^{8}$ The suspect in this case reported:

I get up at seven in the morning, make my bed and clean up my own space and the hallway. I eat breakfast at seven thirty after being called by my own name. The amount of the meal is pretty small, and all I have for a breakfast is a bowl of rice, miso-soup, side-dish and pickles. I am not allowed to drink anything but a glass of warm water. There is no way to keep my stomach filled without buying food or asking my relatives to bring food for me before the sun sets. I can bathe only three times a week. Bathing is not allowed if the investigation lasts too

8 Yamashita, "Human Rights of Prisoners", Hogaku Seminar, October 1988. 
long at night. The tatami mat is made of vinyl, which sticks to my body and makes me very uncomfortable. The police keep my clothes and underwear. Washing clothes is allowed only three times a week when I am allowed to take a bath. What I can bring into my own cell are just paper tissues and a handkerchief, after obtaining permission. A pillow and a mattress are available from the police, but they smell terrible with sweat.

I have to greet the police by saying politely that I am entering the room when I step inside the investigation room, and I salute and bow. Investigation by the police is started after saying good morning to them. I am not allowed to move my body except to nod my head. I sit near the edge of the room, whereas the two investigators sit on chairs that are located under an air conditioner. I have not eaten anything for a few days because I do not take enough sleep and feel so tired. Notwithstanding my innocence, I confessed as a result of the continued forcing by the police to confess for about a week. The investigator broke my false teeth, and I cannot chew or eat anything. Investigation is almost like a torture, and I could finally get a better meal after I was finally forced to confess.

It is not allowed to exercise longer than 15 minutes a day. Two cigarettes are allowed a day in an empty room or at the hallway beside the substitute prison. It is prohibited to go outside. Cutting nails and shaving are considered to be exercise, and a nail clipper and a shaver are given. I did not know that there was free time, but even after I knew it, free time means nothing because I am always being interviewed. I cannot get medicine even when I feel sick and ask them to give me some. They tell me to ask the policeman who is in charge of me, and they just ignore what I say. It is up to the particular police officer whether I can read books or not. I bought a book and read it when the investigation was over, for the first time after I was arrested. There is no opportunity to read newspapers and magazines.

I can see my lawyer only for 10 minutes, and they say time is up no sooner than I have started seeing him. All I can remember from meeting with my lawyer is if my family is doing OK or not. They call the roll at seven at night. I wait until my name is called after I pick up my pillow and mattress from the closet. A police officer stands in front of each cell, and they examine everywhere (such as pocket, blanket, mattress and futon mat) to see that we do not have anything dangerous. After they finish examining, they give us a permission to enter our own cell. I feel miserable and horror. There are more things such as these than I could describe.

According to a Ministry of Justice Departmental Notice of 25 May 1967, detainees are required to sit only on their heels in the cell, and it is prohibited for them to stretch out the legs, lie down, stand up or walk around. ${ }^{9}$ These are only some of the examples of what is going on in substitute prisons in Japan, and there are cases similar to this every day.

9 Departmental Notice on Outlines for the Implementation of Detention of Suspects, 25 May 1967. 
As the example above shows, suspects of crimes are not only treated as if they were already convicted, but they are also examined by investigators for a long time in the investigation room. The food, accommodation and clothes provided in substitute prison are terribly bad in quality. Suspects suffer from mental isolation and lack of sleep, resulting in extreme exhaustion. Moreover, it is true that prisoners get better treatment if they confess, and by doing so, they can get better meals, cigarettes, medication, permission to exercise, and so on. It follows that substitute prison is being used as a means of obtaining (sometimes false) confessions, and it often results in false charges.

\section{Violation of International Treaties}

The condition of prisoners in substitute prison is in violation of article 5 of the Universal Declaration of Human Rights, and article 10 of ICCPR. It is also in violation of article $14.3(\mathrm{~g})$ of the ICCPR since prisoners in the substitute prisons are in a condition where they can easily be forced to confess against their will and best interests.

Rule 84(2) of the Standard Minimum Rules requires that prisoners under arrest or awaiting trial (untried prisoners) should be presumed to be innocent and should be treated as such. The Rules also guarantee other kinds of freedom to untried prisoners such as to have their food procured at their own expense from the outside, either through the administration or through their family or friends (Rule 87); to wear their own clothing (Rule 88); to procure books, newspapers, writing materials and other means of occupation (Rule 90); to be visited and treated by their own doctor or dentist (Rule 91); to be given all reasonable facilities for communicating with family and friends and for receiving visits from them (Rule 92). Taking all of these and other rules into account, it will be clearly in violation of the rules of Standard Minimum Rules for prison authorities in Japan to prohibit or limit a prisoner's right to exercise, smoke, receive medication, interviews, read books and newspapers, and use a library. In any event, the condition of substitute prisons in Japan is unacceptable because, as is illustrated above, the primary effect of substitute prison is to put suspects in hardship and to make interrogation painful. The system of substitute prison has no sense or philosophy of honouring suspects' dignity and treating them as human beings.

\section{A SUSPECT IN HANDCUFFS}

\section{A Introduction}

A hospital is a public facility where everyone goes to see doctors or to be hospitalized. Many visitors walk down hallways or wait in the hallways when receiving medical examination especially in big and general hospitals such as those established by universities and other public corporations. In these circumstances, a suspect was brought to a hospital where many patients and visitors could observe him handcuffed. Anyone in his position would feel as if he were brought before a public place in front of a town hall 
or, as was the case in feudal Japanese society, were publicly being brought through the streets down to the final place of execution.

\section{$B$ Facts of the Case}

The defendant was indicted as one of the conspirators in a murder case. However, he claimed his innocence. The case was still pending in the District Court of Osaka. The defendant, ie the plaintiff in this state compensation case, ${ }^{10}$ had been in custody since August 1985 for more than 10 years. In December 1990, the defendant suffered from cataracts and almost lost his sight. But the authorities had left him without medical treatment for about a year. The Osaka Detention Centre had even obstructed his attorneys' efforts to end the detention, by submitting a diagnosis claiming that the alleged treatment was not necessary. The defendant was finally able to have medical treatment at Osaka Red Cross Hospital after a court order of temporary stay of execution of detention in December 1991. However, after the expiration of the stay he was recommitted to detention, after his operation in March 1992.

On April 1, 1992, just after his re-committal to detention, he was brought to the same hospital in Osaka, accompanied by two prison officers. At the hospital, he was forced to walk in hallways and waiting rooms with his hands handcuffed and with a waist rope attached to him. The hospital was crouded by many patients waiting for treatment in the hallway. Out of curiosity and fear, patients and nurses were trying to avoid coming closer to the party, observing them from a distance. The defendant felt so ashamed but could do nothing but endure. On the next day, he spoke to his lawyers about the "treatment" and the humiliation with his eyes full of tears.

At the civil suit seeking for a state compensation against Japan, ${ }^{11}$ the plaintiff sought damages as a result of torts on the part of the public authority for denial of adequate medical treatment and for the "treatment of marching in the hospital".

The Osaka District Court rejected the claim of denial of adequate medical treatment, approving the discretion on the part of the doctor for the treatment. However, the court awarded damages of 100,000 yen for the plaintiff on the claim of the "marching in the hospital". The court stated that the prison officers' acts were in violation of the plaintiff's rights of privacy to his personal character and that they conspicuously lacked consideration for the plaintiff's personal character, ie honour of the plaintiff as a human

10 This is a case where the plaintiff sued the state of Japan for compensation and consolation of 1.3 million yen. The case was presented by Mr Yasuhiko Nakamura, Mr Shinji Akita and Mr Kiyoshi Yamashita, all of whom are affiliated to the Osaka Bar Association.

11 State Compensation Act of 1947, c 125, art 1. The decision is Watanabe v Japan, Osaka District Court 30 January 1995. 
being and his right to life as human person, because the plaintiff was brought around the hospital under the circumstances where his handcuffs and waist ropes were easily observed by outpatients and visitors who were waiting for their treatment in the hallways of the hospital. The defendant state appealed to the Osaka High Court, but the 10th Civil Division Court of the Osaka High Court dismissed the appeal on 30 October 1996, with the award of damages increased to 130,000 yen for the plaintiff.

Finally, on April 10, 1998, the Supreme Court of Japan dismissed the appeal by the state and approved the judgment of the Osaka High Court. ${ }^{12}$

\section{The Meaning of the Ruling}

The Osaka High Court considered human rights as deriving from the "dignity as a human being and rights to live as a human being," and it admitted that the prison authority invaded these rights. It is interesting to examine how the concept of these rights was formed in the mind of the judges of the court.

The main question is whether it becomes an act of substantially invading human dignity to keep a suspect or a defendant handcuffed and tied to a rope during an examination or investigation of police officers and/or public prosecutors, or during the transportation from the detention facility to a court room, or even during a trial.

Professor Koji Sato of the University of Kyoto Faculty of Law states that the concept of human rights has various meanings in it, from those theoretical in nature to those concrete in actual cases. One kind of human rights is categorised as the human rights substantiating other human rights, while another is classified as human rights as legal rights. The former involves the right of a person as a human being which gave rise to a human right as legal right; these have been claimed and depended on in each era and time of human existence. Human rights as legal rights are found in the provisions of the Constitution, but there are two types of human rights: concrete rights on which protection and remedy can be based and legal enforcement can be claimed, and abstract rights which are not "backed by" concrete rights.

Forcing a suspect or defendant to be brought around with handcuffs and a rope tied to him/her is "an invasion to the dignity of an individual" as provided in article 13 of the Japanese Constitution. It also is a violation of articles 7 and 10 of ICCPR, which provide that no one shall be subjected to inhuman or degrading treatment and that all persons deprived of their liberty shall be treated with humanity and with respect for the inherent dignity of the human person.

12 Judgment of the Second Petty Bench (Presiding Justice, H Fukuda) of the Supreme Court of Japan, reported in "Asahi Shimbun" and "Mainichi Shimbun" on 11 April 1998. 
Respecting a person's dignity can be found in constitutions and treaties all over the world. For instance, article 1 of the German Constitution states that the very first obligation of the national authority is to respect the dignity of human beings. The Preface of the United Nations Charter, the Universal Declaration of Human Rights, the International Covenants of Rights (ICCPR and ICESCR), the European Convention of Human Rights, the UNESCO Charter, and the Fundamental Law on Education in Japan ${ }^{13}$ put emphasis on respect of the dignity of human beings. Thus, respect of the dignity of human beings has already been established as a basic rule of human rights. That is, respect of the dignity of human beings is the foundation for freedom and equality, and it has the most important value in human rights.

The series of judgments in this Osaka case are important and remarkable because they make it clear that the police and prison practices of taking the defendant handcuffed and tied to a rope is an obvious invasion of the "dignity as a human being and right to live as a human being".

\section{The Problem}

First of all, this decision was rendered based on article 13 of the Japanese Constitution. In a decision by the Tokyo District Court on November 20 1987, it was made clear that the article 13 of the Japanese Constitution protected the individual's interest in human rights that is absolutely necessary in protecting an individual's dignity. The court did not say that every single interest in human rights would be protected, because interests in human rights were abstract and had many meanings. However, it did say that actual protection could be guaranteed based on this provision of the Constitution if the object and content of the protection were developed in society and if social agreement is attained on a particular interest for the protection of human character. Thus, it seems that human dignity and the right to live as a human being is evaluated as being substantially protected under the constitutional provision.

Secondly, however, the courts have made no mention of articles 7 and 10 of the ICCPR or about the dignity of human beings and rights to live as human beings as provided under the international treaty. Under these circumstances, the plaintiff's attorneys submitted a lot of proof and evidence relating to international human rights. They presented and in their oral arguments cited information relating to article 7 of ICCPR before the Osaka High Court. ${ }^{14}$

13 Fundamental Law on Education of 1947, c 25.

14 The following and other evidence and documents were submitted to the court: (1) Letters of request by the Osaka Bar Association to the Chief Commissioner of Osaka Prefectural Police, Osaka Public Prosecutors' Office and to Osaka District Court; (2) Submission of a defendant before 
Thirdly, with these efforts on the part of attorneys, it seems that the particular courts have now fully understood the relevant provisions of international treaties such as articles 7 and 10 of ICCPR, and these provisions seem to have played an important role in supplementing the overriding or superior provisions of the Japanese Constitution such as article 13 which provides for the guarantee of individual dignity.

the court in the Kyoto District Court as reported by Yomiuri Shimbun, Mainichi Shimbun, Kyoto Shimbun on September 25, 1992; (3) Japanese translation of Novak's Commentary on ICCPR; a case before the Austrian Constitutional Court; S Brown Hamano on Interpretation of ICCPR; General comments by the Human Rights Committee; other international treaties and guidelines. 